\title{
Bilješka o uredniku
}

Drago Roksandić (Petrinja, 1948.) redoviti je profesor u trajnom zvanju na Odsjeku za povijest Filozofskog fakulteta Sveučilišta u Zagrebu, predstojnik Katedre za povijest Srednje i Jugoistočne Europe, voditelj Ranonovovjekovnog modula Diplomskog studija i nositelj poslijediplomskog doktorskog kolegija „Teorije i metode u modernoj i suvremenoj historijskoj znanosti“. Voditelj je projekta „Triplex Confinium“ (od 1996.) i fakultetskog Centra za komparativnohistorijske i interkulturne studije (od 2014.), Programa Desničini susreti (od 2005.) te projekta Europske unije „Jankovic Castle“ (2011. - 2014.). Član je projekta Local Approaches to the Second World War in Southeastern Europe na Sveučilištu Humboldt u Berlinu. Vidi: H. Petrić, „Živjeti Triplex Confinium (u povodu 60. godišnjice rođenja prof. dr. sc. Drage Roksandića“, Ekonomska i ekohistorija, vol. 4, br. 4, 2008., 151-231 i http://kula-jankovica.unizg.hr. Novija izdanja: „Izlazak izvan zidina“, u: Ivo Goldstein, Slavko Goldstein (ur.), Povijest grada Zagreba. Knjiga 1. Od prethistorije do 1918., Zagreb 2012., 200-251; U NIN-u i Danasu, Zagreb 2011.; Daniel Baric, Jacques Le Rider i Drago Roksandić (ur.), Mémoire et histoire en Europe centrale et orientale, Rennes 2010.; Drago Roksandić i Vlatka Filipčić Maligec, Kultura hrvatskog antifašizma. (Prvi kongres kulturnih radnika Hrvatske (Topusko, 25. - 27. lipnja 1944.). Između „mjesta pamćenja“ $i$ kritičke refleksije, Zagreb 2016.; Zapovidi Babogredske kompanije 1823. - 1824. godine, Zagreb - Babina Greda 2017.; Jugoslavija u istorijskoj perspektivi (ur. Latinka Perović, Drago Roksandić, Mitja Velikonja, Wolfgang Höpken i Florian Bieber), Beograd 2017. Nositelj je dvaju francuskih odličja: časnik reda akademske palme (Officier dans l'Ordre des Palmes Académiques, 2004.) i časnik nacionalnog reda za zasluge (Officier dans l'Ordre National du Mérite, 2014.). 